Kunt, Gergely. "Mapping the Intergenerational Memory of the Holocaust in Hungarian Bystander Families: The Case of Sacha Batthyány's Identity Novel, Und was hat das mit mir zu tun? ['And What Does That Have to Do With Me?']." Hungarian Cultural Studies. e-Journal of the American Hungarian Educators Association, Volume 10 (2017) DOI: 10.5195/ahea.2017.279

\title{
Mapping the Intergenerational Memory of the Holocaust in Hungarian Bystander Families: The Case of Sacha Batthyány's Identity Novel, Und was hat das mit mir zu tun? ['And What Does That Have to Do With Me?']"
}

\section{Gergely Kunt}

\begin{abstract}
In this study, Kunt examines the intergenerational memory of the Holocaust in Hungarian bystander families. Communicative memory plays a key role in intergenerational relationships, as it allows the transmission of the family's own interpretation of the past to younger generations, thereby becoming an important pillar of individual and family identity. Kunt's analysis finds that in the memory of bystander families he has studied in Hungary, the persecution of the Jewish population is only marginally present, for several reasons. One is that the intergenerational communication of such memories has been scarce, as these memories in particular are seldom passed down to the third and fourth generations. Another reason is that the majority of Hungarian society is characterized by a sense of competitive victimhood, where many families impress upon their descendants the severity of their own historical losses while simultaneously dismissing or trivializing the losses of other social groups, often by suppressing memories related to the suffering of such groups.
\end{abstract}

Keywords: Hungarian Holocaust, life writing, bystanders, family memory, Sacha Batthyány, social innovation

Biography: Gergely Kunt, Ph.D., is a social historian and Assistant Professor at the University of Miskolc, Hungary. Kunt teaches the social history of Hungary and East Central Europe. His dissertation was a comparative analysis of the social ideas and prejudices of Jewish and Christian adolescents during World War II as reflected in their diaries. Kunt earned his Ph.D. in history at the University of Budapest (ELTE) in 2013. He has been collecting

\footnotetext{
* The research presented in this study was realized with the support of the European Union and co-financed by the European Social Fund within the framework of the Széchenyi 2020 Program, as part of Project no. EFOP-3.6.1-1600011 titled Rejuvenating and Renewing University - Innovative City of Knowledge - The Institutional Development of Miskolc University for Intelligent Specialization ['Fiatalodó és Megújuló Egyetem - Innovatív Tudásváros - a Miskolci Egyetem intelligens szakosodást szolgáló intézményi fejlesztése’]. This article was translated by Éva Misits.
} 
Kunt, Gergely. "Mapping the Intergenerational Memory of the Holocaust in Hungarian Bystander Families: The Case of Sacha Batthyány's Identity Novel, Und was hat das mit mir zu tun? ['And What Does That Have to Do With Me?']." Hungarian Cultural Studies. e-Journal of the American Hungarian Educators Association, Volume 10 (2017) DOI: 10.5195/ahea.2017.279

privately owned diaries and has acquired numerous unpublished diary manuscripts from the period of the Holocaust and the Communist era. He is one of the founding members of the European Diary Archives and Collections (EDAC). Kunt has been granted a Junior Research Core Fellowship (2017-2018) at the Institute of Advanced Studies at the Central European University. His most recent publication in English is "Wartime Sexual Economy as Seen through a Hungarian Woman’s World War II Diary” (2017). kunt.gergely@gmail.com

\section{Mapping Intergenerational Memory}

In this study, I examine the reasons behind Hungarian society's failure to address the past of the Hungarian Holocaust, with special emphasis on the importance of the collective social processing of the genocide, and the problematic issue of the intergenerational transmission of memories of the genocide within bystander families. Although bystanders constitute the majority of Hungarian society, they have been largely neglected in Holocaust literature, even though recently several studies and volumes have been dedicated to bystanders as a social group. While research has produced a wealth of literature on the intergenerational family memory of persecuted Jewish families, predominantly focusing on the connection between memories of trauma and Jewish identity and exploring the key role of the memory of the Holocaust in shaping Jewish and Israeli identities (Bar-On 1995, Ofer 2009: 1-35, Wardi: 1990), the intergenerational memory of bystander families, especially with regard to the genocide, remains terra incognita to this day. Therefore, I aim to explore the ways in which memories of the Holocaust are transmitted between generations of bystander families, and their effect on the third and fourth generations of grandchildren and great-grandchildren. This is especially relevant because social innovation, which entails an active struggle against prejudice and exclusion in society, cannot be achieved without an honest confrontation of the past for the benefit of future generations.

If we consider the Holocaust as a collective trauma, then theoretically, memories of the Holocaust should be present even in families that were neither perpetrators nor victims of the genocide, but nonetheless played a key role in the process as passive and apathetic bystanders (Bar-On 2001: 125-148, Edgren 2012, Kovács 2016). For the purposes of this study, I shall use Steven Baum's definition, who defines bystander as "generally one who is present, but refrains from involvement" (Baum 2008: 153). While Baum provides a useful definition, his work analyzes the general behavior of bystanders and as such reduces them to a largely homogeneous group, despite the fact that Holocaust scholarship tends to distinguish between several generations of victims and survivors. Holocaust scholarship traditionally distinguishes three generations of Jewish people affected by the Holocaust: the first generation, which personally experienced persecution; the second generation born after 1945; and the third generation born in the 1970s and 1980s. Susan Rubin Suleiman also suggests the use of an additional category, "Generation 1.5," to denote children who were eleven years old or younger during World War II (Suleiman 2002: 283). Scholars who adopt Suleiman's category use it exclusively to denote victims and survivors, but I argue that these categories should also be extended to the non-Jewish population of countries directly involved in the Holocaust, since World War II and the Holocaust can be regarded as collective traumas that devastated entire societies. Although the contemporary experiences, value systems, and narratives of Jewish and non-Jewish persons differed, the war and the Holocaust were traumatic for everyone who personally experienced them, and left traces in all family histories, whether Jewish or non-Jewish. Therefore, I argue that extending the 
Kunt, Gergely. "Mapping the Intergenerational Memory of the Holocaust in Hungarian Bystander Families: The Case of Sacha Batthyány's Identity Novel, Und was hat das mit mir zu tun? ['And What Does That Have to Do With Me?']." Hungarian Cultural Studies. e-Journal of the American Hungarian Educators Association, Volume 10 (2017) DOI: 10.5195/ahea.2017.279

categories of Holocaust literature to the non-Jewish population would allow us to analyze society in its entirety instead of only witnesses, victims, and perpetrators. However, we would also need to readjust these categories to reflect the specificities of a given country's involvement in World War II and the Holocaust. In the case of Hungary, for instance, the first generation would include those who experienced World War II as adults, which means those who were born before 1920 and became adults by the time Hungary entered the war.

According to Jan Assmann, intergenerational contact is predominantly based on oral interaction (Assmann 2008). Speech and communication play a crucial role in communicative memory, since it is through interaction that family members transmit their own version of the past to younger generations. One important aspect of communicative memory is that it "has only a limited time depth which normally reaches no farther back than eighty years, the time span of three interacting generations" (Assman 2008: 111). As Assmann points out, the first forty years following a given event are especially important in communicative memory, because this time frame marks the eventual passing of the generation that once experienced those events as adults.

Events experienced by the first generation become meaningful not at the moment of their occurrence, but later on in the form of the first generation's life narrative and part of their family memory, which consists of the individual narratives of family members constructed from the perspective of the present (Kovács 2008a). In other words, family memories are never exact reports of a given family member's former experiences, but personal narratives of the past constructed according to certain themes, which greatly determine which events and what particular memories are transmitted to the next generation. In this regard, the first generation to experience a particular event plays a crucial role in the communicative memory of their family, since they become the first generation with the power to create their own narrative of the "great events" they had experienced, and impart this narrative to their families. Consequently, the choices of the first generation greatly determine how the next generation with no personal experience will be acquainted with, and come to interpret, certain events in their family's past. In turn, the next generation becomes the first to filter the life narratives of the previous generation, and determine which parts should be preserved or forgotten through communication and omission, respectively. At the same time, this principle applies to every parental generation that passes down their family history to their children, which means that in the case of the third and fourth generations, memories pertaining to the first generation will have been filtered several times by the time they are transmitted to the grandchildren and great-grandchildren of the first generation.

I argue that in transgenerational family memory, themes that influence the construction of life narratives are especially important, and may result in two types of metanarratives based on content and meaning, which I shall call golden age narratives, and victimhood narratives, respectively. While golden age narratives comprise family memories and historical periods with positive connotations, victimhood narratives predominantly center on losses, whether financial, material, or human, which allows the family to identify and sympathize with the sorrows of past generations. Although the loss of material objects might seem absurd to include in the definition of victimhood and loss narratives, they are important to consider in cases where family memory fosters an intensive longing for objects such as family heirlooms. In any given family, however, 
Kunt, Gergely. "Mapping the Intergenerational Memory of the Holocaust in Hungarian Bystander Families: The Case of Sacha Batthyány's Identity Novel, Und was hat das mit mir zu tun? ['And What Does That Have to Do With Me?']." Hungarian Cultural Studies. e-Journal of the American Hungarian Educators Association, Volume 10 (2017) DOI: 10.5195/ahea.2017.279

golden age and victimhood narratives pertain to different events and periods, and greatly determine the political socialization and identity of family members.

Memories communicated within the family carry moral themes as well as positive and negative stereotypes, which strongly influence the next generation's perception of certain social groups. In this regard, victimhood narratives are integral to the construction of identities, because on a personal level, the notion of victimhood is so relative that anyone may present themselves as a victim in their own narrative. Whether a family considers themselves or their ancestors to be the victim, victimhood may result in a positive identity inasmuch as it gives the family a sense of moral superiority, absolves them as passive sufferers from taking responsibility for their actions, and thus protects the family from judgment by their peers (Fülöp et al. 2016: 59-92).

Interestingly, golden age narratives, which are positive by nature, do not play nearly as important a role in the construction of family identity as victimhood narratives do, on account of the fact that victimhood narratives offer a ready distinction of "us" versus "them" by positioning the family as the victims and designating the perpetrators or scapegoats, whether on an individual or collective level. To put it differently, victimhood narratives not only offer members of a community of memory a well-defined position within their imagined social system, but also articulate certain demands, goals, and expectations towards other social groups on account of the community's victimhood.

World War II was a traumatic experience for all families in all countries involved, which means that every member of the first generation could present themselves as a victim, both in personal and in family memory. In the case of Hungary, however, it is important to note that the majority of society did not experience the increasing persecution and eventual genocide of the Jewish population as traumatic, and even facilitated this process as passive bystanders. Moreover, in Hungarian society, victimhood has become a key point of Hungarian national identity, an integral part of which is to present Hungarian history-even in educational textbooks - as the constant persecution of Hungarians by other peoples and nations, such as the Tartars, Turks, Austrians, Germans, and Russians (László and Fülöp 2011: 295-315). Hungarian society also engages in competitive victimhood, exacerbated by the fact that the crimes of both Nazism and communism remain collectively unspoken and unprocessed to this day. On the micro level, competitive victimhood often emerges in family memory, especially the family memory of bystanders, who attempt to emphasize their own historical losses and victimhood while simultaneously trivializing the losses of other social groups. Of course, victimhood narratives will center on different events and memories depending on the family in question, which means that the victimhood narratives of Jewish families will concentrate on the period of genocide, while the non-persecuted majority would focus on the allied air raids, the approaching war front, the Soviet occupation, and the violence and rape committed by the Soviet troops.

One of the most important elements of family memory, regardless of whether the family was a victim, perpetrator, or bystander of the Holocaust, is its focus on the family's own victims and losses, which means that in the case of bystander families, memories of the Holocaust and the massacre of Hungarian Jewish citizens was often either ignored or marginalized. One reason is that Hungarian anti-Semitism refuses to view Jewish citizens as Hungarian, and therefore dismisses their losses as irrelevant to the Hungarian nation. Another reason is that Hungarian society has yet to confront the past, one symptom of which is that narratives related to the 
Kunt, Gergely. "Mapping the Intergenerational Memory of the Holocaust in Hungarian Bystander Families: The Case of Sacha Batthyány's Identity Novel, Und was hat das mit mir zu tun? ['And What Does That Have to Do With Me?']." Hungarian Cultural Studies. e-Journal of the American Hungarian Educators Association, Volume 10 (2017) DOI: 10.5195/ahea.2017.279

Holocaust are either suppressed, or only mentioned in order to plead collective amnesia in the form of "we did not do anything" and "we did not know what was happening." Not only does the omission of such histories erase the memory of the past actions or passivity of the generations of great-grandparents and grandparents, but it also silences the histories of material (dis)possessions, including the confiscated furniture and everyday possessions of deported Jewish families.

Hungarian society suffered a variety of traumas during World War II and the rising communist regime, but the intensity of such memories varies from family to family. Theoretically, if the Jewish population is present in the transgenerational memories of bystander families, then these memories lend themselves to three metanarratives. The first is one of pity and solidarity, and partially of condolence and positive memories of former interethnic relationships. The second comprises memories of either aiding the persecuted minority, or symbolic forms of solidarity, that is, real or imagined actions that primarily serve to foster a positive self-image in the community of memory. Finally, the third narrative contains various grievances the family had suffered from those classified as Jewish. In my research, I found that bystander family memory generally tends to exhibit all three metanarratives in varying constellations.

In Hungarian bystander families, memories of the persecution of the Jewish population are only marginally present in family memory, as illustrated by a recent sociological study that used questionnaires to examine the role of family memory in transmitting knowledge of the ten most important events in twentieth century history. The questionnaire was distributed to a class of high school students in Budapest, who had turned eighteen years old in 2011 (Csákó 2014: 81107), and the ten events in question included World War I, the persecution of the Jewish population, World War II, political show trials under the communist dictatorship, the persecution of kulaks, the Hungarian Revolution of 1956, the political system change of 1989, and finally, Hungary's accession to the European Union. Based on family memory alone, approximately half of the students could not list a single event that had affected their families, which is technically impossible, and therefore suggests the intergenerational failure to transmit family memory in Hungarian society. The study also confirmed that the memory of the persecution of the Jewish population is marginal even in cases where family memory had been transmitted, as this event was rated lowest on the questionnaire. In other words, it would appear that only the persecuted minority considered it important to preserve the memories of persecution within their families. The number and presence of grandparents also affected the persistence of family memory, where families already missing some or all members of the first generation showed a lack of familiarity with family memory.

In Hungarian family memory, we find that the primary role of the grandparents was to preserve the memories of previous generations from the first half of the twentieth century, when the grandparents were only children or had not been born yet, rather than transmit their own life narratives. Due to the fact that Hungary was under a communist regime from the end of World War II until the system change of 1989, we may conclude that grandparents were brave enough to transmit memories passed down to them in the course of communicative family memory, but reluctant to talk of their own personal experiences, as their communication could have endangered their relations. In other words, there is a generational rift in family memory, but it 
Kunt, Gergely. "Mapping the Intergenerational Memory of the Holocaust in Hungarian Bystander Families: The Case of Sacha Batthyány's Identity Novel, Und was hat das mit mir zu tun? ['And What Does That Have to Do With Me?']." Hungarian Cultural Studies. e-Journal of the American Hungarian Educators Association, Volume 10 (2017) DOI: 10.5195/ahea.2017.279

did not so much occur between the parents and grandchildren, as between the grandparents and parents, which researchers assume was due to the exercise of self-censorship during the socialist era. Following the genocide of the Jewish population, Jewish families often concealed their Jewishness and the memory of persecution from their children in order to protect them, while bystanders concealed the history of the persecution of the Jewish minority, and their anti-Jewish collaboration during the war.

Typically, memories of World War II become heavily filtered and anecdotal by the time they reach the third and fourth generations. Theoretically, in the case of the third generation of bystander families, the fact that the Holocaust has become a symbol of universal trauma could play an important role in the third generation's coming to terms with the past and educating themselves about the events. However, the vast majority of Hungarian society appears unaffected and uninterested in this issue, partially because family memory contains no trace of the history of the massacred Jewish population, and even when people do hear of these tragic deaths from former neighbors or friends, they have no interest in pursuing the topic. All of this suggests that despite the increased presence of the subject of the Holocaust in everyday life in the form of film adaptations, educational material, and public discourse, on a personal level, the subject does not resonate with Hungarian audiences. In other words, despite the presence of the subject in everyday life, the majority fails to reflect on the Holocaust and raise the question of, and what does that have to do with me?

When we look at the descendants of former Hungarian bystanders, we find that intergenerational family memory has been so heavily filtered that we could consider any interest in the Holocaust atypical, because their communicative family memories are predominantly centered on different events. For the persecuted Jewish minority, family memory forms a canon and offers basic patterns of remembrance that facilitate the narration of individual narratives of suffering, and can be adapted even by those who belong to subsequent generations. In the case of bystander families, however, such patterns do not exist beyond individual attempts at confronting one's family past. The uncertainty surrounding the almost taboo subject of the persecution of the Jewish population thus produces a unique bystander family memory, where the various actors to whom later generations have become emotionally attached - might not have been perpetrators of violence, but clearly were not heroic allies, either. The complicated situation of bystanders is further compounded by the fact that perpetrators can be easily and openly condemned by their descendants both in a moral and legal sense, while in the case of bystanders, their involvement in the Holocaust is more difficult to determine, leaving their descendants in constant doubt. Why did they do nothing? Or did they in fact do something, but in ways that cannot be traced? Is there no evidence of their involvement in family memory or documents? If they did do something, what did they do? Did they agree with the persecution of the Jewish minority? Did they oppose it, or somehow express their solidarity? These unanswered questions could lead to constant doubt and suspicion in the generation of grandchildren and great-grandchildren, or at least in the atypical minority that cares to raise these questions at all.

One factor that greatly hinders Hungarian society's reconciliation with the past is the fact that victimhood constitutes an integral part of individual and family identity, to the point where everyone appears to be a victim in some shape or form. In order to come to the terms with our history, it would be imperative that social groups carrying different experiences and memories of 
Kunt, Gergely. "Mapping the Intergenerational Memory of the Holocaust in Hungarian Bystander Families: The Case of Sacha Batthyány's Identity Novel, Und was hat das mit mir zu tun? ['And What Does That Have to Do With Me?']." Hungarian Cultural Studies. e-Journal of the American Hungarian Educators Association, Volume 10 (2017) DOI: 10.5195/ahea.2017.279

the past engage in dialogue with each other, and arrive at a more or less mutually shared interpretation of the past. Part of this process would entail acknowledging the various victimhood narratives of other groups as equally valid, thereby mitigating the phenomenon of competitive victimhood.

\section{The Third Generation of Bystander Families and Sacha Batthyány's A Crime in the Family}

To this day, we know little of the struggles of the third generation of bystander families to confront and process the past, which is why it is important to examine Swiss journalist Sacha Batthyány's self-castigating novel, originally published in 2016 in Germany with the title, Und was hat das mit mir zu tun? ['And What Does That Have to Do With Me?']. Batthyány was born in 1973 in Switzerland to former Hungarian aristocrat parents, and his novel shows how he confronted the active and passive participation of his relatives in the Holocaust as their grandchild. Within the same year of publishing his book, it was translated into French, Dutch, and Hungarian with the original title intact (Batthyány 2016), while the Italian version published that same year changed the book's title to Le bestie di Rechnitz ['The Beasts of Rechnitz'], and the English version published in 2017 changed the title to A Crime in the Family. In the English version, crime refers to the fact that Sacha Batthyány was inspired to write his novel when, while working as a journalist, he was informed by one of his colleagues that in the final days of World War II, his aunt Margit participated in the anti-Jewish massacre in Rechnitz, Austria. This is what the Italian title refers to by using the phrase bestie ['beasts'], coupled with the site of the massacre, as part of the novel investigates and describes the crime that involved Batthyány's aunt. However, Batthyány's novel also includes two accidentally acquired memoirs, one written by Batthyány's grandmother, and the other written by his grandmother's Jewish childhood friend, Ágnes Mandl. During his investigation of his family's past, Batthyány visited Rechnitz, the former site of the massacre; Sárosd, where his grandmother and Mandl had grown up; and the concentration camp in Kistarcsa, where Mandl had been interned before her deportation to Auschwitz. Mandl managed to survive the genocide and later settled in Argentina, where Batthyány paid her a visit. The book, which was based on Batthyány’s research, travels, and experiences, traces the life narratives of Batthyány's grandmother, and also the story of his grandfather, who was deported to Siberia for forced labor after the Soviet occupation of Hungary.

The English, German, and Hungarian reviews of Batthyány's novel viewed it as mere sensationalist journalism centered on the unclear involvement of Batthyány's aunt in the Rechnitz massacre, and the same narrow interpretation can be gleaned from the English and Italian titles referencing the massacre, but on closer examination, I found that Batthyány's work is an example of the operation of personal and family memory in a bystander family. In spite of the horrors it documents, I consider Batthyány's book an identity novel, because the narrative focuses on his search for identity, and describes how confronting his family's past affected him personally. The most important question Batthyány raises in his novel concerns the extent to which he is similar to and different from the ancestors whose life narratives he tried to trace through writing and traveling - his great-grandparents, his grandparents, and his father. The novel also documents Batthyány’s recurring attempts to process the personal trauma of confronting his family's past in the course of therapy sessions with his psychologist in Zürich. 
Kunt, Gergely. "Mapping the Intergenerational Memory of the Holocaust in Hungarian Bystander Families: The Case of Sacha Batthyány's Identity Novel, Und was hat das mit mir zu tun? ['And What Does That Have to Do With Me?']." Hungarian Cultural Studies. e-Journal of the American Hungarian Educators Association, Volume 10 (2017) DOI: 10.5195/ahea.2017.279

The self-analytical aspects of the novel are further highlighted by the fact that Batthyány reports his experiences and observations in first person singular, merging reality and fiction in a way that occasionally blurs the boundaries between the two (so that the novel might be called a type of autofiction as described in Vasvári 2009: 27).

The novel begins in the early 2000s, when Batthyány was informed by a colleague that his aunt Margit, in whose company he had been obliged to spend many unpleasant family lunches in his youth, was not just a barely tolerable relative, but played an important role in the Rechnitz massacre at the end of World War II. Margit was born in 1911 with the surname Thyssen-Bornemisza, and though she married into the distinguished Batthyány family in the 1930 's, she actually owed her massive wealth to the Thyssen line of industrial tycoons. Following the war, she moved to the family's estate in Lugano, and eventually immigrated to Switzerland. Sacha Batthyány, who was born and raised in Switzerland after his parents had defected in 1956, met his aunt Margit as a child, and for a while, his most prominent memory of her was the way Margit often stuck out her tongue in conversation. According to Batthyány's information, his aunt Margit played an important but still unclear role in the events of March 24, 1945, when she held a party at her castle in Rechnitz, Burgenland, close to the AustrianHungarian border. That night, SS leaders and other Nazis invited to the castle murdered some two hundred Hungarian Jewish labor service conscripts as part of the event, then proceeded to eat and drink through the night. As the date shows, the massacre took place in the last days of World War II, a scant two weeks before the Soviet troops liberated the town of Rechnitz.

Rechnitz, the site of the anti-Jewish massacre in which Batthyány's aunt was involved, has since become a symbol of the controversial and incomplete Austrian process of confronting and processing the past. Following the events, the local population sank into silence, and has remained silent to this day because, as Éva Kovács points out, they still do not acknowledge the victims as their own. Although Rechnitz has become an important Holocaust memorial site in Austria, this ultimately allowed Austrians to overlook their own role and responsibility in the persecution and genocide of the local Jewish population (Kovács 2008b: 5-14). By adopting a narrative about foreigners, namely Hungarian and German agitators, German perpetrators, and Hungarian Jewish victims, Austrians shifted the focus away from their own responsibility under the guise of Holocaust remembrance, as if the narrative did not involve them in any way.

In 1956, after the Batthyány family lost its wealth and source of income when their properties were expropriated during the forced land redistributions of 1945, Batthyány's parents defected to Switzerland in 1956 completely impoverished. To start over in the West, Batthyány's aunt Margit, one of the wealthiest persons in the family, and in Europe for that matter, aided the family both financially and through her connections. She not only managed to secure a job for Batthyány's grandfather Ferenc at one of the German Thyssen factories, but also arranged for the enrollment of Batthyány's father Bálint, who was fourteen years old at the time, into one of the most prestigious Swiss institutions so he could resume his high school studies. Batthyány's novel suggests that as the wealthiest member of the family, his aunt Margit sought to cover up her involvement in the Rechnitz massacre, and her financially vulnerable relatives accepted her offer of support in exchange for their silence until and even after Margit's death in 1989. In fact, the family kept her secret so faithfully that Sacha Batthyány was only informed of Margit's darker side as an adult and from an external source. 
Kunt, Gergely. "Mapping the Intergenerational Memory of the Holocaust in Hungarian Bystander Families: The Case of Sacha Batthyány's Identity Novel, Und was hat das mit mir zu tun? ['And What Does That Have to Do With Me?']." Hungarian Cultural Studies. e-Journal of the American Hungarian Educators Association, Volume 10 (2017) DOI: 10.5195/ahea.2017.279

Sacha Batthyány’s book includes two memoirs, one written by Batthyány's paternal grandmother, countess Margitta Esterházy, and the other written by her Jewish childhood friend, Ágnes Mandl, whose parents operated a gas station and general store in the settlement of Sárosd, where the Esterházy family resided at Esterházy Castle. Mandl, who moved to Budapest during the war, was taken to the internment camp in Kistarcsa following the German occupation of Hungary in March 1944, and then deported to Auschwitz. She managed to survive, and in October 2013, Sacha Batthyány traveled to Buenos Aires to meet her, and during that visit Batthyány received Mandl's memoirs from her Argentinian relatives, who were in charge of the elderly Holocaust survivor's documents.

We do not know to what extent Batthyány edited the contents of Mandl's memoirs, but parts of the memoir were included in his book to run parallel with relevant passages from the German-language memoir of Margitta Esterházy, Batthyány’s grandmother, who not only wrote of her own childhood, but also recorded how in 1944, her father refused to aid Mandl's parents, who were soon shot on the castle grounds by one of the German soldiers staying at the castle. News of the German soldier's crimes was suppressed by the grandmother's father, who exerted his influence over the authorities and had the case closed as a double suicide. As late as 2013, Mandl and her descendants believed that her parents had indeed committed suicide to escape deportation, but the grandmother's memoirs revealed the circumstances under which Mandl's parents had been executed, which grieved the grandmother until her death.

Victimhood played an important role in shaping the collective memory and identity of the aristocratic Batthyány family, who regarded themselves as victims of communism after they had lost everything under the dictatorship of Mátyás Rákosi, and were eventually forced to flee from Hungary. Their material losses were exacerbated by the fact that in 1945, Batthyány's grandfather was deported to the Soviet Union, where he spent ten years working as an asbestos miner in the town of Asbest at the Eastern base of the Ural Mountains, while his wife and oldest son, Batthyány's father, remained in Hungary to live in abject poverty. Due to the grandfather's internment, his son spent ten years without a father, which later affected his eventual relationship with his own son Sacha, who often described their conflicts and how, despite their attachment to each other, he and his father were unable to communicate and understand each other. They were, however, united by the family memory of victimhood, as the most shocking and personal parts of Batthyány's book pertain to his travels to Siberia with his father, where they sought the ruins of the forced labor camp where the author's grandfather had once worked, then visited the mining community where his grandfather had mined asbestos. Based on these passages, it would appear that the crimes of communism were the greatest source of grief in the memory of the Batthyány family, since the family completely denied its involvement in the Rechnitz massacre by remaining silent even after the death of the potential perpetrator(s).

According to an interview with Sacha Batthyány, his book contains both real and fictive elements. One of the most easily identifiable instances of the latter is a scene where a Nazi soldier and a communist agent meet at Lake Balaton in the 1980's, when the tourist attraction served as a meeting point between East and West. Batthyány also included another character, a Hungarian prostitute from Zürich called Linda, whom he had met on a train bound for Budapest. Batthyány met Linda several times by coincidence, and during these meetings, he offered Linda his help, as well as talked of his investigation of his family's past, which Linda listened to with 
Kunt, Gergely. "Mapping the Intergenerational Memory of the Holocaust in Hungarian Bystander Families: The Case of Sacha Batthyány's Identity Novel, Und was hat das mit mir zu tun? ['And What Does That Have to Do With Me?']." Hungarian Cultural Studies. e-Journal of the American Hungarian Educators Association, Volume 10 (2017) DOI: 10.5195/ahea.2017.279

confusion and disinterest. The parts detailing Linda's everyday life and background do not seem to fit the themes and issues of the book, but I would argue that they serve a double function. On the one hand, by dedicating parts of his book to a prostitute, the author is able to show his solidarity towards exploited and marginalized members of society, and on the other, the prostitute's reaction illustrates how the actual subject of the book - the individual and family difficulties inherent in coming to terms with the past—is far removed from the struggles of everyday life.

Unfortunately, Batthyány does not explicitly mark the boundaries between reality and fiction in his book, which casts doubt on the authenticity of the memoirs that form the bulk of his narrative. In an interview, when the authenticity of the memoirs was called into question, Batthyány said the following: "It's a report book that contains fictional elements. I am a writer and writing is my tool, I confront these things by writing about them. However, my grandmother's and Ágnes Mandl's diaries are real, as are our conversations, and my travels from Argentina to Kistarcsa" [Riportkönyv, amelyben vannak fikciós elemek. Író vagyok, az írás az eszközöm, és úgy konfrontálódom ezekkel a dolgokkal, hogy írok róluk. Nagyanyám és Mandl Ágnes naplója azonban valódiak, ahogyan a beszélgetéseink, és az utazásaim is Argentínától Kistarcsáig] (Kövesdi 2016). Given the very sensitive nature of the subject, it would have been more helpful to the reader if the boundaries had been clearly marked. Despite Batthyány's claims of having used authentic sources, my impression upon reading the excerpts remains that, if the memoirs are indeed real, he had carefully and heavily edited them, and as he never disclosed the extent to which he had edited his sources, it is probable that Batthyány omitted certain parts of the memoirs when he adapted them for his novel.

In March 2016, certain documents Batthyány used for his novel were presented in an interview on Kulturplatz, a program hosted by Swiss Radio and Television (Schweizer Radio und Fernsehen, SRF). During the interview, Batthyány showcased several documents, including his grandmother's German-language memoirs, his grandfather's gulag documents, and family photographs of his aunt Margit. Mandl's memoirs, however, were not presented, though this does not necessarily mean that they do not exist. At the same time, Batthyány also failed to explain how he had adapted the memoirs in his book, other than mentioning how his grandmother's memoirs were disorderly and lacking transparency, with no indication of the length of her memoirs beyond "hundreds of pages, most of them handwritten" (Batthyány 2017: 124). This confirms that Batthyány heavily edited his grandmother's memoirs, who herself had probably exercised self-censorship when she wrote them in her old age.

Batthyány never disclosed how he had edited his sources, but we may presume that if the memoirs he used are real, then he edited them to serve the interests and aims of his own book, or, perhaps, to make his account appear more authentic. From this perspective, we cannot rule out the possibility that he might have included fictional elements in the excerpts as well. As we shall see, the two memoirs also overlap and support each other in ways that cast further doubt on their veracity, such as excerpts related to Kistarcsa, to be discussed below. In the absence of evidence, it is possible that one of the memoirs did exist, while the other was made up by Batthyány himself. All this, in my opinion, suggests that parts pertaining to the memoirs should be approached with reservation. At the same time, I argue that the possible fictive nature of certain 
Kunt, Gergely. "Mapping the Intergenerational Memory of the Holocaust in Hungarian Bystander Families: The Case of Sacha Batthyány's Identity Novel, Und was hat das mit mir zu tun? ['And What Does That Have to Do With Me?']." Hungarian Cultural Studies. e-Journal of the American Hungarian Educators Association, Volume 10 (2017) DOI: 10.5195/ahea.2017.279

parts of the book does not lessen its merits at all, as I consider it an authentic personal account of the struggles of the third generation in confronting and processing the past.

The question Batthyány raises in the original title of his book (And what does that have to do with me?) is incredibly important, because the true aim of the book is to ponder, and somehow answer the question of what the genocide has to do with the third generation. In this regard, Aunt Margit's role in the Rechnitz massacre is secondary to Batthyány's primary concern, which is to understand how he relates to the events and experiences of his relatives. In other words, during his travels, Batthyány's dilemma revolves not around his aunt's potential involvement, but around answering the question of what Batthyány himself might have done in a similar situation. This question, however, is raised not in connection with the potential perpetrator, but in relation to Batthyány's paternal grandmother and to his great-grandparents:

[W]hat distinguished my grandmother's parents from Aunt Margit? . . . They were not bloodthirsty monsters. My relations had not tortured or shot anyone. They had simply watched and done nothing, they had stopped thinking, they had stopped existing as human beings although they knew what was going on (Batthyány 2017: 175).

Batthyány was troubled by the fact that according to his grandmother's memoirs, she and Batthyány's great-grandfather denied their Jewish acquaintances' requests for help, which remained a source of guilt until his grandmother's death. On this subject, the grandson asked himself the following questions:

Would I have acted differently from my grandmother on that afternoon long ago? Would I have opposed a father who didn't want to step in and do something? Would I have kept him from hushing up the murders? Have I ever really opposed anything? No, why would I? After all, everything in Switzerland is just fine, I hear myself replying (Batthyány 2017: 180).

In light of the excerpts above, Batthyány's book can be considered a special case of confronting and processing the past, one that highlights the difficulties, issues, and contradictions inherent in bystander family memory. In my opinion, these parts are what make the book so remarkable, as we hardly know any other sources on the struggles of a younger generation to explore and process the past of their bystander ancestors, who had not only trivialized the Holocaust in order to emphasize their own victimhood, but also concealed their involvement as Nazi collaborators.

In Batthyány's book, the most important bystander figure is his paternal grandmother, as evidenced by the grandson's desperate attempts to prove to himself and his readers that his grandmother was not completely passive during the Holocaust. To this end, Batthyány dedicated the final chapter, and his last journey to the ruins of the Kistarcsa internment camp, to the 
Kunt, Gergely. "Mapping the Intergenerational Memory of the Holocaust in Hungarian Bystander Families: The Case of Sacha Batthyány's Identity Novel, Und was hat das mit mir zu tun? ['And What Does That Have to Do With Me?']." Hungarian Cultural Studies. e-Journal of the American Hungarian Educators Association, Volume 10 (2017) DOI: 10.5195/ahea.2017.279

memory of his grandmother. His visit was motivated by a passage in his grandmother's memoirs, where she claimed that she had traveled from Sárosd to Kistarcsa on her own in an attempt to visit her interned friend, but was unable to see her. Batthyány doubted the veracity of his grandmother's statements, because it seemed highly improbable that his grandmother would have been brave enough to risk such a journey alone during a dangerous period, when she was only twenty-two years old, and pregnant with her second son. Batthyány suspected that his grandmother might have made up these passages to lessen her feelings of guilt brought on by her passivity; however, Ágnes Mandl's memoirs found in Argentina supported the grandmother's passages, as Mandl recorded that someone had been looking for her at the internment camp, but was not able to meet her. It is important to note at this point that we are still uncertain whether Mandl's memoirs or the lines about Batthyány's grandmother's visit to Kistarcsa truly exist. It is possible that Batthyány partially or completely invented Mandl's memoirs based on his grandmother's memoirs or the information he received during his personal visit to Ágnes Mandl. At any rate, the idea that the two memoirs mutually confirmed the events convinced Batthyány that his grandmother was not completely passive during the Holocaust, as did the last part of the memoirs, in which his grandmother recorded how, as a symbolic gesture of solidarity with the stigmatized Jewish population, she wore a yellow daffodil as her own yellow star.

In his book, Batthyány ultimately absolves his grandmother from complete passivity by showing examples of her symbolic solidarity and subtle gestures of rebellion, but his desperate attempts to do so are indicative of the struggles of the first generation of bystanders and their grandchildren and great-grandchildren. The memory of any symbolic gestures of solidary have long since been lost, which forces the third and fourth generations to wonder whether to imagine their ancestors as exceptions, or accept that they were like the majority and simply went with the flow, whether they harbored hatred or apathy. In the case of bystander families, I also found that processing the Holocaust on a micro level, that is, on a personal or family level, is made especially difficult by the later generations' emotional ties to the relatives they are to judge for their involvement, or lack thereof. As the case of Batthyány's aunt Margit shows, the relationship of the third or fourth generation to the first generation they had met as children could be negative as well as positive, but where emotional ties are positive, they make it especially difficult, if not impossible, to process the memory of the involvement of said relatives in the Holocaust, especially the extent and manner of their involvement.

In conclusion, Batthyány's book is an authentic report of the struggles of the third generation to process the past, as the author is not only mortified by the apathy of his grandmother and great-grandfather, but also haunted by the question of whether he is any different from his ancestors. "Wasn't I one of them too-and the thought alarmed me: wouldn't I myself have been different if they had done something at the time, instead of simply standing by and watching?" (Batthyány 2017: 173). The author's crippling doubt surfaces several times in the novel until it is explicitly addressed in several ways as he asks himself, "I don't know if I could do a thing like that - hiding Jews," or elsewhere, "If there was war of the same kind as seventy years ago, wouldn't we all be fellow travelers?" (Batthyány 2017: 128, 180). I would argue that today, the answer of the masses would be an enthusiastic Yes, but this is mere fantasy and self-conceit, and only lasts while the audience naively imagines itself in popular film roles as heroes fighting against the evil Nazis. In reality, in the last seventy years after the Holocaust, we 
Kunt, Gergely. "Mapping the Intergenerational Memory of the Holocaust in Hungarian Bystander Families: The Case of Sacha Batthyány's Identity Novel, Und was hat das mit mir zu tun? ['And What Does That Have to Do With Me?']." Hungarian Cultural Studies. e-Journal of the American Hungarian Educators Association, Volume 10 (2017) DOI: 10.5195/ahea.2017.279

have not known a single instance of genocide that was ultimately prevented by the majority's solidarity with the persecuted minority, and their refusal to become apathetic bystanders. Of course, there are always individual exceptions, but these are few and far between, which proves that Batthyány did confront himself and his family's past with honesty when he dared to answer his own question with a seemingly strange and politically incorrect No. No, he would not be "hiding Jews," and no matter how painful and shocking the answer sounds, it reflects our reality better than Yes.

\section{Works Cited}

Assmann, Jan. 2008. "Communicative and Cultural Memory." In Cultural Memory Studies: An International and Interdisciplinary Handbook. Eds. Astrid Erll and Ansgar Nünning. New York: Walter de Gruyter: 109-118.

Bar-On, Daniel. 1995. Fear and Hope: Three Generations and the Holocaust. Cambridge: Harvard UP. . 2001. "The Bystander in Relation to the Victim and the Perpetrator: Today and During the Holocaust." Social Justice Research 14.2: 125-148.

Batthyány, Sacha. 2016. És nekem mi közöm ehhez? A családom története [“And What Does That Have to Do With Me? The Story of My Family']. Budapest: Helikon Kiadó.

- 2017. A Crime in the Family. London: Quercus.

Baum, Steven K. 2008. The Psychology of Genocide: Perpetrators, Bystanders, and Rescuers. New York: Cambridge UP.

Csákó, Mihály. 2014. "Családi emlékezet és történelem” ['Family Memory and History’]. Társadalomtudományi Szemle 4.1: 81-107.

Edgren, Henrik ed. 2012. Looking at the Onlookers and Bystanders: Interdisciplinary Approaches to the Causes and Consequences of Passivity. Stockholm: Forum för Levande Historia.

Fülöp, Éva et al. 2016. “Áldozat és még inkább áldozat. A kollektíváldozat-szerep zsidó családok transzgenerációs narratíváiban" ['Victim and Even More of a Victim: The Role of Collective Victimhood in the Transgenerational Narratives of Jewish Families']. Imágó Budapest 5.3-4: 59-92.

Kovács, Éva ed. 2008a. Tükörszilánkok - Kádár-korszakok a személyes emlékezetben ['Mirror Shards: The Kádár Era as Reflected in Personal Memory']. Budapest: MTA Szociológiai Kutatóintézet.

—. 2008b. “Ártatlan tettesek - néma közösségek: A rohonci mészárlás és a soá 'globális emlékezete"” ['Innocent Perpetrators, Silent Communities: The Rechnitz Massacre and the "Global Memory" of the Shoah']. 2000: Irodalmi és társadalmi havi lap 20.6: 5-14.

Kovács, Mária. 2016. Kollektív emlékezet és holokausztmúlt ['Collective Memory and the Past of the Holocaust']. Budapest: Corvina Kiadó.

Kövesdi, Péter. 2016. "Sacha Batthyány: Szívesebben vagyunk áldozatok” ['Sacha Batthyány: We Prefer to Be Victims']. Vasárnapi hírek. https://www.vasarnapihirek.hu/fokusz/ sacha_batthyany_szivesebben_vagyunk_aldozatok 
Kunt, Gergely. "Mapping the Intergenerational Memory of the Holocaust in Hungarian Bystander Families: The Case of Sacha Batthyány's Identity Novel, Und was hat das mit mir zu tun? ['And What Does That Have to Do With Me?']." Hungarian Cultural Studies. e-Journal of the American Hungarian Educators Association, Volume 10 (2017) DOI: 10.5195/ahea.2017.279

László, János, and Fülöp Éva. 2011. "Nemzeti identitás és kollektív áldozati szerep” ['National Identity and the Collective Role of the Victim']. Pszichológia 31.3: 295-315.

Ofer, Dalia. 2009. "The Past That Does Not Pass: Israelis and Holocaust Memory.” Israel Studies 14.1: 1-35.

Suleiman, Susan Rubin. 2002. "The 1.5 Generation: Thinking about Child Survivors and the Holocaust." American Imago 59.3: 277-95.

Vasvári, Louise O. 2009. "Kertész Imre Sorstalanságának újszerüsége" ['The Novelty of Imre Kertész's Fatelessness']. Múlt és jövö 20.3: 21-31.

Wardi, Dina. 1990. Memorial Candles. Jerusalem: Keter Publishing House. 